\title{
Feeding habits of blue swimming crab Portunus segnis (Forskal, 1775) in the northern coastal waters of Iran
}

Mohsen Safaie

\begin{abstract}
Background: The study of food and feeding habits of crab has manifold importance in fishery sciences. The blue swimming crab Portunus segnis is an opportunistic predator and the diet of which depends on local availability of food items. The distribution and biological aspects of crabs are largely dependent on the availability of preferred prey organisms.
\end{abstract}

Methods: Feeding habits of the blue swimming crab, P. segnis were studied in the northern Persian Gulf by trawl nets during the period from May 2010 to April 2012. The stomach contents of 1722 crabs, ranging from 36 to 175 $\mathrm{mm}$ carapace width, were analyzed.

Results: The stomach contents appeared to consist of mainly large quantities crustaceans, fish and molluscs, also small quantities of unidentifiable matter and debris. Based on the major food groups were observed in different season, the crustaceans was the most dominant in summer (56\%) and the fish items and Mollusca were the most dominant in autumn (67\%) and winter (45\%) respectively.

In Juvenile and sub adult crabs, crustaceans constituted the dominant food source and these were present in $56.7 \%$ and $45.1 \%$ respectively. In the adult groups and larger size groups, fish were the principal food item and these were present in $44.5 \%$ and $53.5 \%$ respectively, of the stomachs analyzed.

There were no difference observed in the quantity of the food consumed in both sexes and also significant differences observed in the preference for food items in the different size groups.

The crabs without barnacle comparatively voracious with barnacle-carrying crabs. Their diet also increased with increasing ovary stages while that the percentage of empty stomachs in ovigerous females was higher than non-ovigerous females.

The C.V. index varied significantly in both sex that was ranged between $6.9-56.0 \%$ and $16.5-48.0 \%$ for male and female, respectively.

Conclusions: This study shows that, despite the diversity in blue crab diets and feeding habits, there are carnivores with a preference for animal food and the behavior of active predators of sessile and slow-moving macro-invertebrates. It is suggested that a major reduction in availability of one prey group would not have a major effect on the crab population.

Keywords: Dietary compositions, Carapace width, Portunus segnis, Persian Gulf and Oman Sea, Iran 


\section{Background}

According to study by Apel and Spiridonov (1998) about 48 species of Portunid crabs was observed in the Persian Gulf and Oman Sea, that only 4 species including Scylla serrata (Forskål, 1775), Portunus segnis (Forskal, 1775), P. sanguinolentus (Herbst, 1783) and Charybdis feriata (Linnaeus, 1758) are important shellfish commodities of commercial fisheries in the south of Iran. The blue swimming carb (P. segnis) occur in west Indian Ocean; western Indian Sub-continent, Pakistan, Persian Gulf, Red Sea, Mediterranean Sea and East coast of Africa (Lai et al. 2010).

The study of food and feeding habits of crab has manifold importance in fishery sciences. The distribution, growth, reproduction, behavior and migration rate of crabs are largely dependent on the availability of preferred prey organisms (Sanchez-Paz et al. 2006; Vinagre et al. 2007).

Knowledge of the dietary habits of a species is essential for understanding its nutritional requirements and thus its interactions with other groups of animals. This information is also useful for its successful culture. Crabs include filter feeders, sand cleansers, mud, plant, and carrion feeders, predators, commensals, and parasites (Dall and Moriarty 1983). The crab uses its mouthparts to chop the food into small pieces and then the gastric mill ossicles further reduce the food to unidentifiable fragments. The majority of researchers use the foregut contents to study the quantity and nature of the different food items the crab has consumed (Williams 1981; Sukumaran and Neelakantan 1997; Chande and Mgaya 2004; Josileen 2011).
Previous studies on crab stocks in the northern Persian Gulf have mainly focused on population parameters, estimation biomass and size distribution and reproductive biology of blue swimming crab (Kamrani et al. 2010; Safaie et al. 2013a, b; Safaie et al. 2015) and on some biological aspects of P.pelagicus in north western Persian Gulf (Jazayeri et al. 2011; Hosseini et al. 2012). The sole study on Dietary Compositions of the blue swimming crab $P$. segnis have been studied by Pazooki et al. (2012) in Boushehr coastal waters, south Iran.

For several years now, Hormuzgan has been the major fishing ground for $P$. segnis in Iranian waters of the Persian Gulf and Oman Sea. Despite its importance in these fisheries, however, there is no information on the diet and preferred food items of the species from this area. The present study has been undertaken to investigate the food and feeding habits of $P$. segnis along the coast of Hormuzgan and the results of some information in this study may be potentially interesting to trophic studies in this species.

\section{Methods}

The crab specimens were collected during daytime by commercial catches of shrimp bottom trawlers in the Hormuzgan area (Fig. 1) extending from $26^{\circ} 25^{\prime} \mathrm{N}, 57^{\circ}$ $29^{\prime} \mathrm{E}$ to $27^{\circ} 07^{\prime} \mathrm{N}, 56^{\circ} 06^{\prime} \mathrm{E}$. Samples were collected during a period from May 2010 to April 2012.

After recording sex composition and the carapace width (C.W.) and carapace length (C.L.) of the crab, the dorsal side of the body was dissected and the foregut was removed carefully. In order to relation between

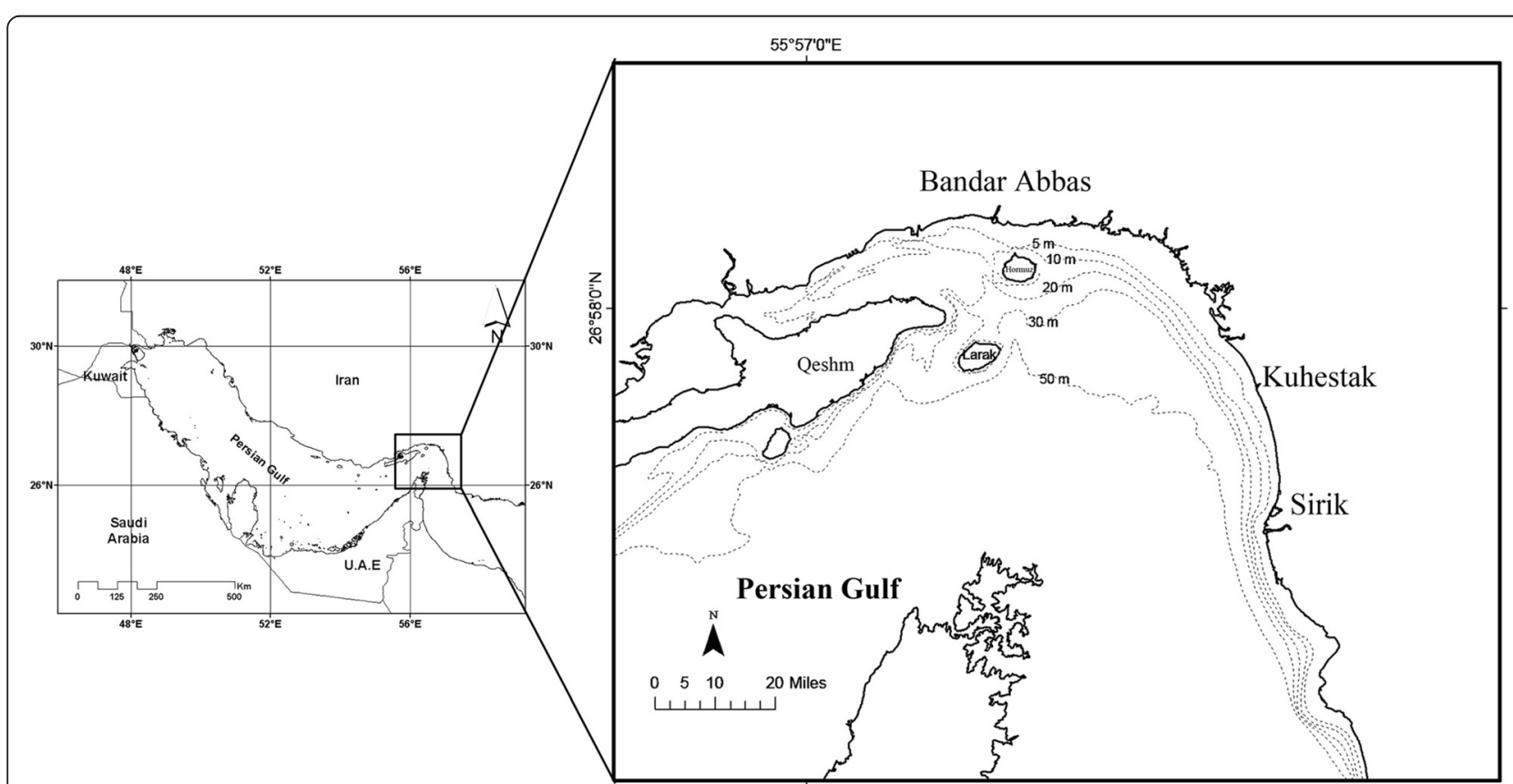

Fig. 1 Study area for Portunus segnis in the Persian Gulf and Gulf of Oman 
feeding and gonad maturity stage in female crab, after its carapace was opened the maturity stages of the ovaries was recorded. The maturity stages of ovaries were grouped into five stages included four main classes and ovigerous stage (stage 5) following the procedure adopted by Kumar et al. (2000).

The vacuity index $(\mathrm{CV})$ is the percentage ratio between the numbers of empty stomachs $E S$ and the total number of stomachs analyzed TS (Biswass 1993:

$$
C V=\frac{E S}{T S} \times 100
$$

The CV indices data were normally distributed, thus the data were kept untransformed. The differences in $\mathrm{CV}$ index between different sex and months were determined using two way ANOVA test. Also, one way ANOVA test was used for determined relation between occurrences of barnacle [Chelonibia patula (Ranzani, 1820)] on outer surface of carapace and CV index in P.segnis.

Studies on food and feeding were adapted from Sukumaran (1995). The fullness of the stomach was visually examined and assessed as $0,25,50,75$, or $100 \%$. The foreguts were preserved in $10 \%$ formalin for a week, prior to being cut open and their contents transferred into Petri dishes with distilled water. The food components of the gut contents were separated and identified under a stereomicroscope.

The most of food items were found to be unidentifiable as a result of having been highly crushed and hence only the hard structures that could be identified were relied upon for determining food composition and further evaluation. Gut contents were broadly classified into five Categories, as follows:

1. Crustacean remains - penaeid shrimp appendages; body parts of crabs and crab eggs and stomatopod parts.

2. Fish remains - fins, scales, bones, and vertebrae.

3. Mollusca remains - parts of bivalve and gastropod shells.

4. Miscellaneous-sea grass, seaweed, foraminifera and unidentified items.

5. Debris - sand, mud and plastic (gillnet fragments).

For each specimen, the whole stomach content was segregated according to food-groups, and each group's contribution was determined visually. Dominance of food groups was evaluated by ranking them by their percentage frequency of occurrence and so-called percentage points (see further below). The percentage frequency of occurrence was estimated as:
No. of stomachs with particular food group $\times 100$ Total no. of stomachs with food

To estimate the volume of the food by food-group, points were assigned to each group as suggested by Stehlik (1993). Percentage points were estimated as:

\section{$\frac{\text { Point of particular food group } \times 100}{\text { Total points of allfood groups }}$}

For the percentage point method, after the stomach was removed it was scored from 1-5, according to the degree of fullness, i.e., approximately $100 \%$, $75 \%, 50 \%, 25 \%$ and $0 \%$. Food categories were given a value ranging from $0-100$ according to the percentage of the stomach contents of a given individual represented by that category. The number of points that each category received was weighted according to the actual fullness of the stomach in which it was found. For example, in a stomach that was half full and contained $25 \%$ molluscs and $75 \%$ crustaceans, the molluscs received a score of 12.5 points, the crustaceans a score of 37.5 points.

\section{Results}

Out of 1722 individuals (865 male and 857 female) of P.segnis were analyzed, in male crabs which 520 $(60.12 \%)$ contained (trace-full) stomachs and 345 (39.88 \%) empty stomachs and in females 576 (67.21\%) contained and 281 (32.79\%) empty stomachs were observed. The CV index (for both sexes) showed monthly decline fluctuations from October 2010 to September 2011. Also, the highest and lowest values for males were observed in December (56.0) and August (25.6), February (52.6) and September (6.9), September (56.0) and August (6.9) for 2010, 2011 and 2012 respectively. While, in female crabs the order mentioned were observed in November (60.9) and May (18.2), May (38.9) and July (7.1), February (31.3) and March (9.1) (Fig. 2). There was no significant differences between means of vacuity stomachs for both sex in different months, but there was a significant difference $(\mathrm{p}<0.05)$ between means of vacuity stomachs of female and male during survey.

The relation between occurrence of barnacle C. patula and $\mathrm{CV}$ indices, also relation between these indices with ovary maturity stages of $P$. segnis in the study area are given in Figs. 3 and 4. Based on the results presented in Fig. 3, it can be the crabs without barnacle comparatively voracious with barnacle-carrying crabs. Their diet also increased with increasing ovary maturity stage while that the percentage of empty stomachs in ovigerous females (stage 5) was higher than non-ovigerous females (Fig. 4).

The stomach contents of Portunus segnis appeared to consist of mainly large quantities crustaceans, fish and 


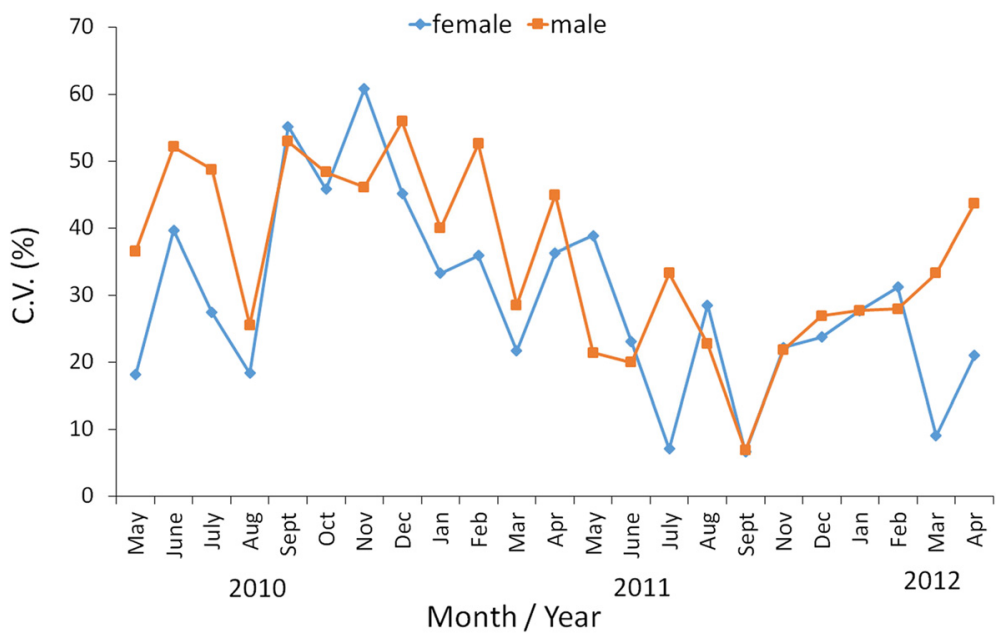

Fig. 2 Monthly fluctuation of $C V$ index of $P$. segnis in the study area

molluscs, also small quantities of unidentifiable matter and debris. Out of the 865 stomachs examined of males, $21.50 \%$ were $100 \%$ full; $13.53 \%$ were $75 \%$ full; $13.76 \%$ were $50 \%$ full; $11.33 \%$ were $25 \%$ full; and $39.88 \%$ were empty. For female crabs (857 stomachs examined), $28.12 \%$ were $100 \%$ full; $17.97 \%$ were $75 \%$ full; $10.85 \%$ were $50 \%$ full; $10.27 \%$ were $25 \%$ full; and $32.79 \%$ were empty. The details by month and according to the size of the crabs are given in Tables 1 and 2 .

Whenever food was found in any stomach, it always consisted of a mixture of various food groups. Upon analysis, it was found that the percentage frequency of occurrence of Crustaceans items comprised $49.47 \%$; Fishes $46.72 \%$; Molluscs 26.64 \%; Miscellaneous $16.07 \%$; and Debris 15.64\%; (Table 3).
The points of the major food groups (by size and by season) are given in Figs. 5 and 6. In the percentage of points, Crustaceans was the most dominant food group, and was found in $39.84 \%$ of the stomachs 'with food'. This fraction consisted primarily of decapods (parts of shrimps, like rostrum, parts of exoskeleton, appendages; and crab exoskeleton fragments, appendages, and eggs), and further contained the remains of stomatopods (like telson and raptorial claw). In different size groups of crabs, the total of crustacean remains varied between 18.3 and $56.7 \%$.

The second dominant food item was fish remains. These were present in $38.75 \%$ of the stomachs. The percentage points of 'fish remains' varied between 22 and $53.5 \%$. Fish food dominated in the stomach contents of

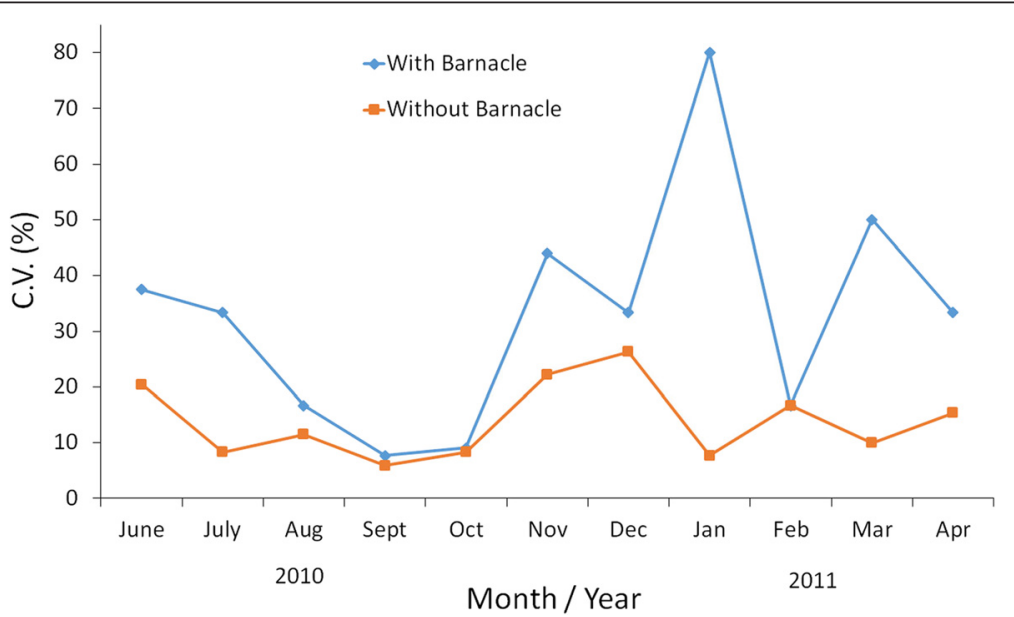

Fig. 3 Monthly effect of occurrence barnacle on CV index of $P$. segnis in the study area 


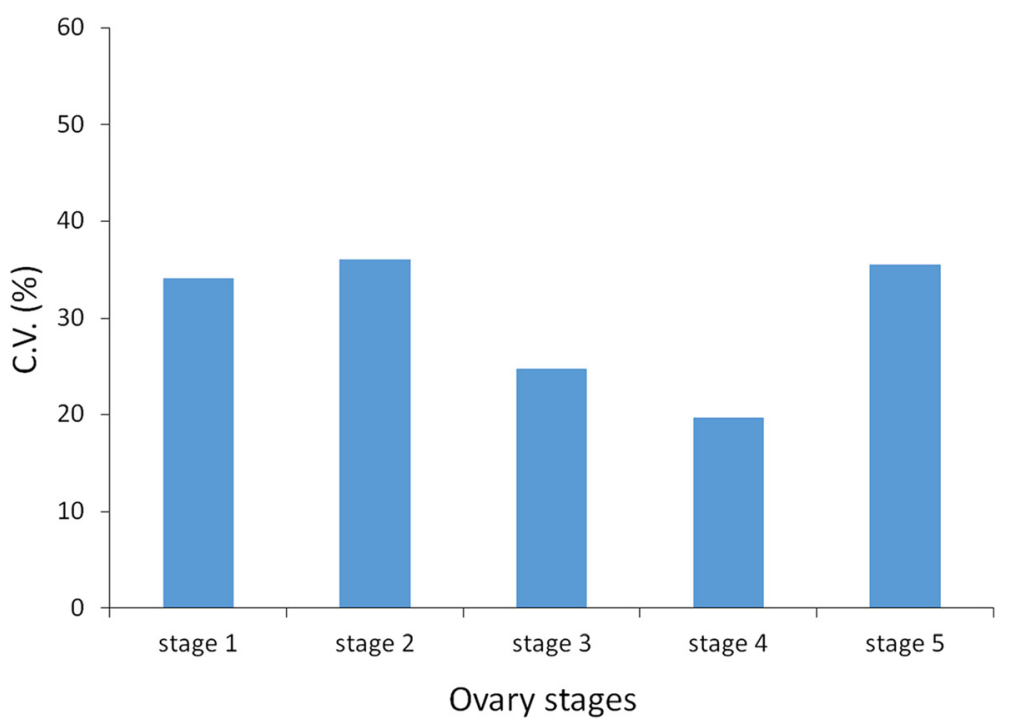

Fig. 4 Relation between CV index and gonad maturity stage of P.segnis in the study area

the larger size groups of the crab (115-144 and 145-174 carapace width in $\mathrm{mm}$ ). Mollusca formed the third most important food item, mainly comprising shell fragments of bivalves and gastropods. It ranged between 11.6 and $26.8 \%$ in the various size groups and the maximum percentage was observed in the larger size groups (115144 and $145-174 \mathrm{~mm}$ ).

The 'miscellaneous' group mainly comprised crushed plant material originating from seaweeds and sea grasses, etc. This group was present in the majority of the stomachs and varied between 1.2 and $9.5 \%$. Detritus was present in $3.19 \%$ of the stomachs.

Their percentages of points in the different size groups varied between 0.2 and $56.7 \%$. In Juvenile crabs (<85 mm CW) appeared to prefer crustaceans (56.7\%) followed by fish (22\%), Mollusca (11.6\%) and miscellaneous items $(8.7 \%)$. In the sub adult group (86-115 mm $\mathrm{CW})$, crustaceans $(45.1 \%)$ were the major food item followed by fish (31\%), Mollusca (13.5 \%), miscellaneous and debris items $(9.5 \%)$ and $(0.9 \%)$ respectively. In adult groups (116-145 and 146-175 mm), fish were the principal food item, however in the larger size group of adults (141-180 mm), Mollusca formed the second most important food item.

The points of major food groups by season (Fig. 6), crustaceans was the most dominant in summer, and was found in $56 \%$ of the stomachs with food, Whereas the other large quantities, the fish items and Mollusca were the most dominant in autumn $(67 \%)$ and winter (45\%) respectively. The other food items include miscellaneous and detritus, were the most abundant in spring (15.5\%) and winter $(15 \%)$ respectively. There were no significant differences in the preference for food items in the different season of the crab $(P>0.05)$.

\section{Discussion}

Knowledge of feeding regimes of species is of great importance in understanding their ecological interaction. Understanding crab feeding habits requires extensive field and laboratory studies to infer the main sources of nutrition for a species. Even then, feeding studies can identify the prevalence of food items but it is not possible to assess the diet preferences of crab without detailed complementary studies to estimate the range and abundance of potential food items available in their natural environment (Biswass 1993).

In this research, the C.V. index for the whole study period was ranged between $6.9-56 \%$ and $16.5-48 \%$ for male and female respectively. Also the means of vacuity varied significantly in both sex, implying a high feeding rate or a slow digestion rate in this species.

The result showed that $P$. segnis is an omnivorous species; this conforms with the findings of several respects to the diet of other portunid crabs. Pazooki et al. (2012) and Josileen (2011) were reported for similar species and P.pelagicus respectively, that those species have similar diet component. The research results showed that they are all opportunistic omnivores with a preference for animal prey, but within that framework only rarely feed on more mobile prey such as fish and prawns (Patel et al. 1979; Williams 1982). In the present study, it is observed that crustaceans constitute the most favored item in this species' diet, followed by fish and molluscs. This conforms to 
Table 1 Stomach fullness during various months in Portunus segnis

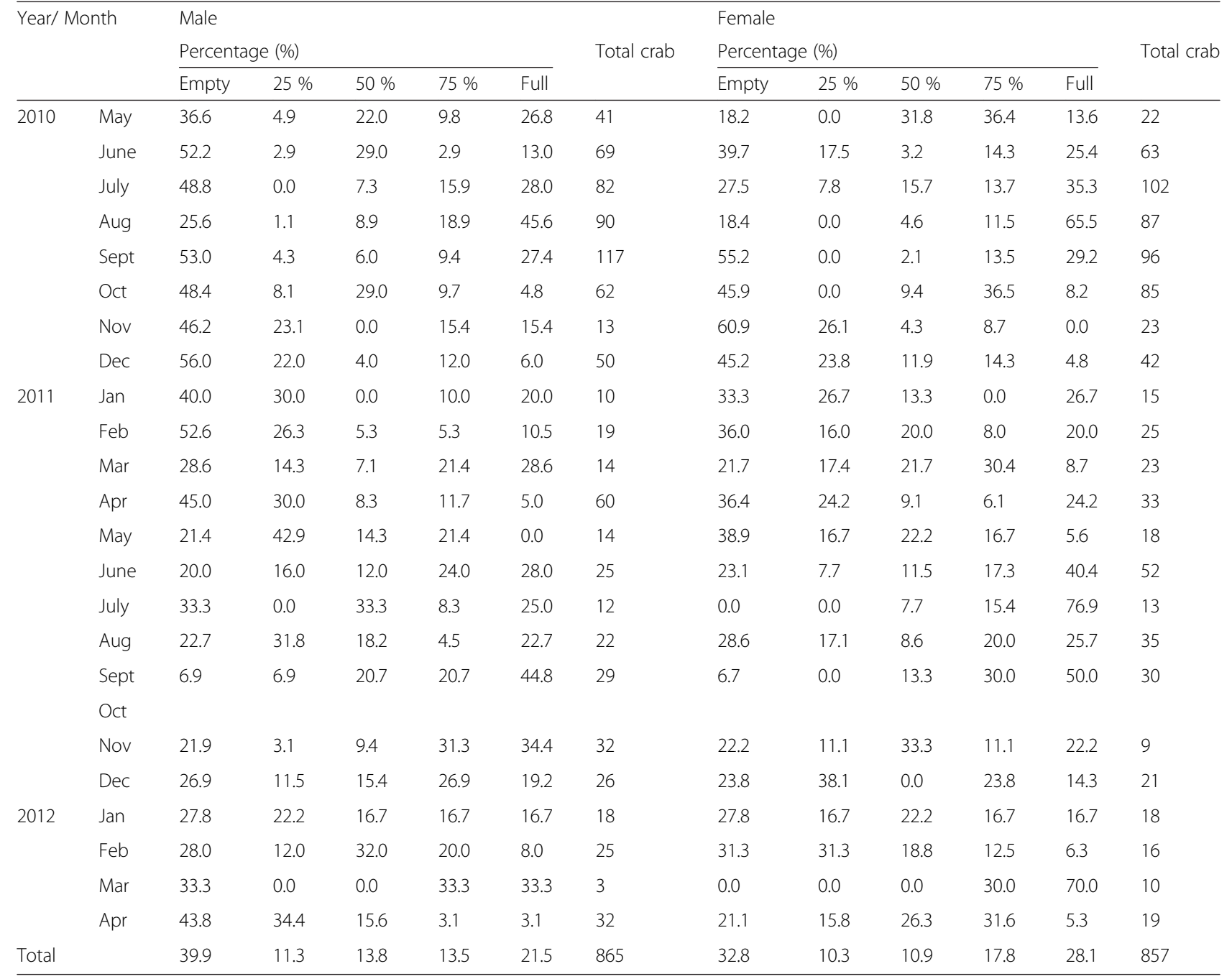

Table 2 Stomach fullness in different size groups (Carapace width in $\mathrm{mm}$ ) of Portunus segnis

\begin{tabular}{|c|c|c|c|c|c|c|c|c|c|c|c|c|}
\hline \multirow[t]{3}{*}{ Size class } & \multicolumn{6}{|l|}{ Male } & \multicolumn{6}{|l|}{ Female } \\
\hline & \multicolumn{5}{|c|}{ Percentage (\%) } & \multirow[t]{2}{*}{ Total crab } & \multicolumn{5}{|c|}{ Percentage (\%) } & \multirow[t]{2}{*}{ Total crab } \\
\hline & Empty & $25 \%$ & $50 \%$ & $75 \%$ & Full & & Empty & $25 \%$ & $50 \%$ & $75 \%$ & Full & \\
\hline $36-55$ & 28.6 & 7.1 & 14.3 & 14.3 & 35.7 & 14 & 60.0 & 0.0 & 0.0 & 40.0 & 0.0 & 11 \\
\hline $56-75$ & 52.1 & 6.3 & 8.3 & 16.7 & 16.7 & 48 & 52.9 & 13.7 & 9.8 & 9.8 & 13.7 & 49 \\
\hline $76-95$ & 37.7 & 10.4 & 15.6 & 13.0 & 23.4 & 154 & 31.5 & 6.5 & 13.7 & 16.9 & 31.5 & 124 \\
\hline $96-115$ & 41.9 & 10.5 & 14.3 & 11.2 & 22.1 & 256 & 32.7 & 8.9 & 7.3 & 21.4 & 29.8 & 246 \\
\hline $116-135$ & 38.4 & 11.0 & 13.9 & 15.2 & 21.5 & 236 & 35.1 & 10.3 & 9.5 & 14.5 & 30.5 & 263 \\
\hline $136-155$ & 36.3 & 16.9 & 12.9 & 15.3 & 18.5 & 123 & 26.8 & 17.0 & 13.4 & 19.6 & 23.2 & 112 \\
\hline $156-175$ & 44.1 & 11.8 & 8.8 & 11.8 & 23.5 & 34 & 17.3 & 7.7 & 23.1 & 25.0 & 26.9 & 52 \\
\hline Total & 40.0 & 11.3 & 13.8 & 13.6 & 21.7 & 865 & 32.8 & 10.2 & 10.7 & 18.0 & 28.0 & 857 \\
\hline
\end{tabular}


Table 3 Percentage of points and frequency of occurrence of major food groups in Portunus segnis

\begin{tabular}{llll}
\hline Items & Points & \% of Points & \% of frequency of occurrence \\
\hline Crustacean & 9979 & 39.84 & 49.47 \\
Fish & 9706 & 38.75 & 46.72 \\
Mollusscan & 3460 & 13.81 & 26.64 \\
Miscellanous & 1103 & 4.40 & 16.07 \\
Debris & 800 & 3.19 & 15.64 \\
\hline
\end{tabular}

the findings of Patel et al. (1979) and Sukumaran and Neelakantan (1997) for P.pelagicus, while also Pazooki et al. (2012) reported the crustaceans constitute the most favored item, followed by molluscs and fish in Boushehr coastal waters for P.segnis. Chande and Mgaya (2004) reported that molluscs, particularly the bivalve Arcuatula arcuatula (Hanley, 1843), were the most important food items in the stomachs of $P$. pelagicus along the coast of Dar es Salaam, Tanzania. Al-Behbehani (2007), also reported that molluscs and crustaceans were the dominant food items in the stomachs of $P$. pelagicus from Kuwait waters.

The wide foraging strategy of $P$. segnis is also typical of other portunid crabs. All species studied so far have been reported to consume mixed diets of crustaceans, fishes and molluscs, similar to P. segnis (e.g., Scylla serrata: Hill 1976; Callinectes sapidus: Laughlin 1982; Scylla tranquebarica and S. serrata: Joel and Raj 1986; S. serrata: Prasad and Neelakantan 1988; Thalamita crenata: Cannicci et al. 1996).
The considerable amount of detritus in their guts has shown that $P$. segnis is also an opportunistic deposit feeder, just as reported by Prasad and Neelakantan (1988) for Scylla serrata and for P.pelagicus (Josileen 2011). The detrital energy assimilated by the crab population is thus converted partly into body tissues (Macintosh 1984). Many portunids also consume small quantities of macrophytes. The adults of Necora puber (Linnaeus, 1767) are found to consume plant material (brown algae) even by preference (Choy 1986). Grapsid, xanthoid, majid, potamid, and portunid crabs (in portunids particularly juveniles) have also been reported to consume plant material (Hill 1976; Paul 1981; Jewett and Feder 1982; Williams 1982; Rosas et al. 1994). In the present study, the stomach contents of juveniles and of sub-adult crabs contained semi-digested plant material, like remains of seaweeds and sea grasses mixed with sand, mud and gravel. Josileen (2011) and Patel et al. (1979) have reported the presence of fair amounts of organic matter mixed with sand, mud, gravel, and other bottom particles, which indicates the species' bottom feeding habits in its bottom habitat.

There was no difference observed in the quantity of the food consumed by males and females of P.segnis in this study, as also reported earlier by Williams (1981), Jewett and Feder (1982), Sumpton and Smith (1990), Wieczorek and Hooper (1995) and josileen (2011) for P.pelagicus.

The majority of crabs with empty stomachs encountered during the study were either in berried condition.

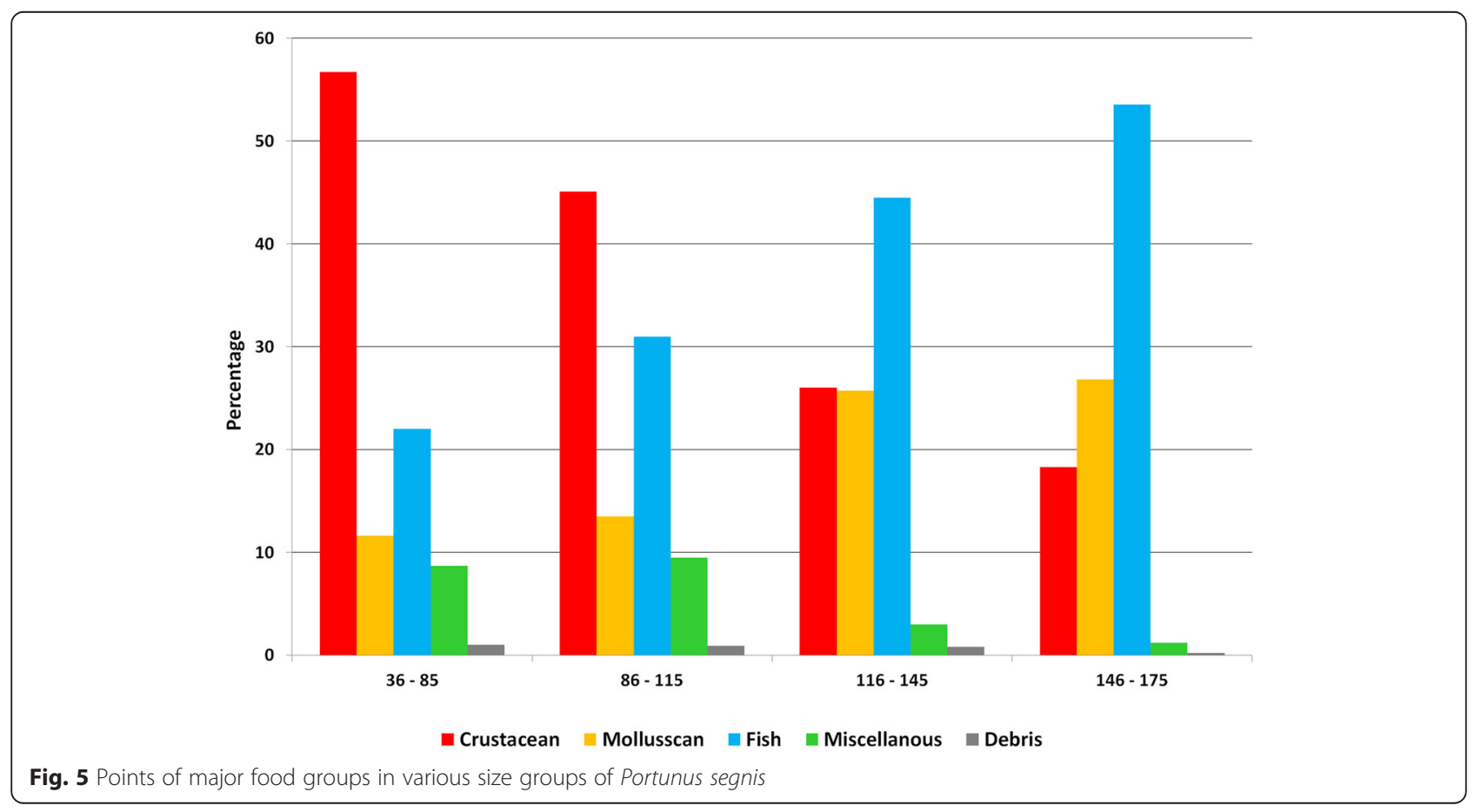




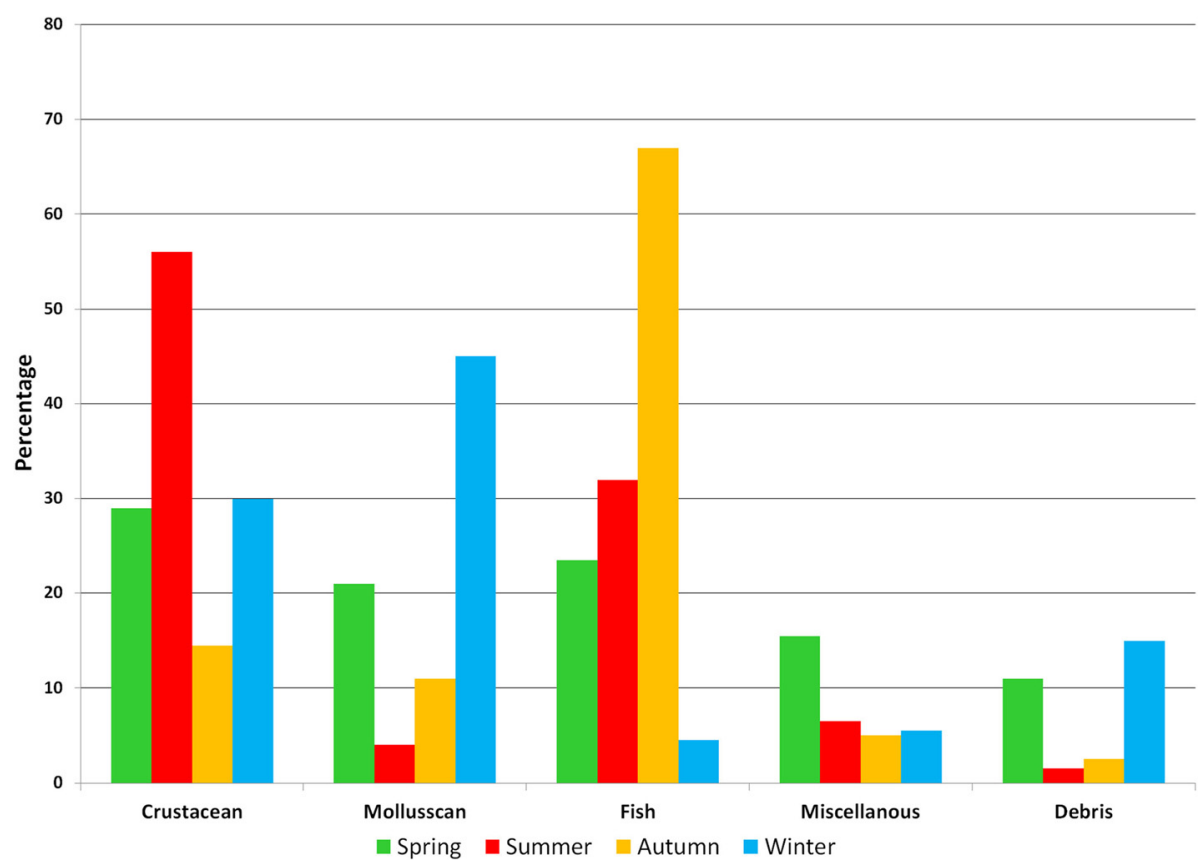

Fig. 6 Points of major food groups during various seasons in Portunus segnis

Choy (1986) also reported empty stomachs in ovigerous females and in parasitized crabs. Jewett and Feder (1982) reported that feeding increases during spring in the king crab, Paralithodes camtschaticus. However, in Portunus segnis no such variation was observed, as Iran is, of course, a tropical country and consequently does not have such sharp seasonal differentiation.

It is not possible to deduce from stomach contents whether a prey item was alive or not when consumed. Caine (1974) had explained a prey catching mechanism in the portunid crab, Ovalipes guadulpensis Rathbun, 1930, but Hill (1976) was unable to observe such a technique in Scylla serrata. Prasad et al. (1985) have observed mud crabs catching live prawns in a prawn culture field during harvesting seasons. Hence, the incidence of animal remains in the gut contents may indicate that the crabs might have opted for dead and decaying material by scavenging. Yet, the presence of crab exoskeleton matter in the stomach contents also shows that they are cannibalistic. Cannibalism was observed on several occasions in the rearing tanks, especially during moulting when the bodies of the newly moulted crabs are soft and vulnerable to attack by the hard-shelled crabs. In the present study, it was observed during several occasions that crabs were consuming the exuviae of other crabs. Hence there are ample chances that the crab remains recorded from the stomachs may be the result of cannibalistic consumption. Thus, the present study, as earlier related studies, suggests that, despite the diversity in crab diets and feeding habits, portunid crabs are opportunistic omnivores with a preference for animal food, also along the coast of Hormuzgan, Iran.

\section{Conclusions}

Given the results of present study and other similar studies cited above strongly suggest that crustaceans, molluscs and fishes were the most commonly ingested items throughout the study period. Thus, the present study, as earlier related studies, suggests that, despite the diversity in crab diets and feeding habits, portunid crabs are carnivores with a preference for animal food and the behavior of active predators of sessile and slow-moving macro-invertebrates. This study also shows that blue swimming crab $P$. segnis consumes a variety of food items. It is suggested that a major reduction in availability of one prey group would not have a major effect on the crab population.

\section{Abbreviations \\ Not applicable.}

\section{Acknowledgments}

I would like to thank Mr. Mohammad Momeni and Dr. Mohammad Sedigh Mortazavi (Iranian Fisheries Research Organization) for providing sampling opportunities and also grateful to several members of the fishing cooperative at Hormozgan Province for their cooperation and assistance during field sampling. 


\section{Funding}

Not applicable.

\section{Availability of data and materia}

Not applicable.

\section{Authors' contributions}

The author read and approved the final manuscript. Also, agree to publish my manuscript in the Marine Biodiversity records Journal.

\section{Competing interests}

The author declares that he has no competing interests.

\section{Consent for publication}

Not applicable.

\section{Ethics approval and consent to participate}

In this study all examined specimens were by catch and discard materials.

Received: 30 June 2016 Accepted: 1 July 2016

Published online: 01 August 2016

\section{References}

Al-Behbehani BE. Biological studies on the blue crab Portunus pelagicus and its parasitic infection in Kuwaiti waters. J Egypt Soc Parasitol. 2007:37(1):215-25.

Apel M, Spiridonov VA. Taxonomy and zoogeography of the portunid crabs (Crustacea: Decapoda: Brachyura: Portunidae) of the Arabian Gulf and adjacent waters. Fauna Arabia. 1998;17:159-331.

Biswass SP. Manual of methods in fish biology. New Delhi: South Asia publishers PVT Ltd; 1993. p. 157p.

Caine RA. Feeding of Ovalipes guadulpensis and morphological adaptations to a burrowing existence. Biol Bull Woods Hole. 1974;147:550-9.

Cannicci S, Dahdouh-Guebas F, Anyona D, Vannini M. Natural diet and feeding habits of Thalamita crenata (Decapoda, Portunidae). J Crustacean Biol. 1996; 16(4):678-83.

Chande Al, Mgaya YD. Food habits of blue swimming crab Portunus pelagicus, along the coast of Dar es Salaam. West Indian Ocean J Mar Sci. 2004;3(1):37-42.

Choy SC. Natural diet and feeding habits of the crabs Liocarcinus puber and $L$. holsatus (Decapoda, Brachyura, Portunidae). Mar Ecol Prog Ser. 1986;31:87-99.

Dall W, Moriarty DJW. Functional aspects of nutrition and digestion. In: Bliss DE, Mantel LH, editors. The biology of Crustacea, 5, Internal anatomy and physiological regulation. New York: Academic Press; 1983. p. 215-51.

Hill BJ. Natural food, foregut clearance-rate and activity of the crab Scylla serata. Mar Biol Berlin. 1976;34:109-16.

Hosseini M, Vazirizade A, Parsa Y, Mansori A. Sex ratio, size distribution and seasonal abundance of blue swimming crab, Portunus pelagicus (Linnaeus, 1758) in Persian Gulf Coasts, Iran. World Appl Sci J. 2012;17(7):919-25.

Jazayeri A, Papan F, Savari A, Saki Nejad T. Biological Investigation of Persian Gulf blue swimmer crab (portunus pelagicus) In Khuzestan coasts. J Am Sci. 2011; 7(2):7-13.

Jewett SC, Feder HM. Food and feeding of king crab Paralithodes camatschatica near Kodiak Island, Alaska. Mar Biol Berlin. 1982:66:243-50.

Joel DR, Raj PJS. Food and feeding of the two species of Scylla (De Haan) (Portunidae: Brachyura). J Mar Biol Assoc India. 1986:28(1-2):178-83.

Josileen J. Food and feeding of the blue swimmer crab, Portunus pelagicus (Linnaeus, 1758) (Decapoda, Brachyura) along the coast of Mandapam, Tamil Nadu, India. Crustaceana. 2011;84(10):1169-80.

Kamrani E, Sabili AN, Yahyavi M. Stock assessment and reproductive biology of the blue swimming crab, Portunus pelagicus in Bandar Abbas Coastal Waters, Northern Persian Gulf. J P G. 2010;1(2):11-21.

Kumar M.S, Ferguson G, Xiao Y, Hooper G. and Venema S. Studies on Reproductive biology and distribution of the blue swimmer crab (Portunus pelagicus) in South Australia waters. Adelaide: SARDI Research Report Series No. 47; 2000.

Lai JCY, Ng PKL, Davie PJF. A Revision of the Portunus pelagicus (Linneus, 1758) species complex (Crustacea: Brachura: Portunidae), with the recognition of four species. The Raffles Bull Zool. 2010;58(2):199-237.

Laughlin RA. Feeding habits of the blue crab, Callinectes sapidus Rathbun, in the Apalachicola estuary, Florida. Bull Mar Sci. 1982;32(4):807-22.

Macintosh D. J. Ecology and productivity of Malaysian mangrove crab populations (Decapoda: Brachyura). Proceedings of the Asian Symposium on
Mangrove Environment Research and Management, University of Malaya and UNESCO;1984. pp.354-377.

Patel NM, Chhaya ND, Bhaskaran M. Stomach contents of Portunus pelagicus (Linn.) from AD net catches. Indian J Mar Sci. 1979:8:48-9.

Paul RK. Natural diet, feeding and predatory activity of the crabs Callinectes arcuatus and C. toxotes (Decapoda, Brachyura, Portunidae). Mar Ecol Prog Ser. 1981;6:91-9.

Pazooki J, Hosseini M, Vaziri ZA. The Dietary Compositions of the Blue Swimming Crab, Portunus segnis (Forskal, 1775) from Persian Gulf, South Iran. World App Sci J. 2012;20(3):416-22.

Prasad PN, Honnavar R, Neelakantan B. The mud crab Scylla serrata (Forskål) as a pest in the prawn culture fields adjoining Kali estuary, Karwar. Sea Food Export J. 1985:17:6-7.

Prasad PN, Neelakantan B. Food and feeding of the mud crab Scylla serrate (Forskål) (Decapoda: Portunidae) from Karwar waters. Indian J Fisheries. 1988;35(3):164-70

Rosas C, Lazaro-Chavez E, Buckle-Ramirez F. Feeding habits and food niche segregation of Callinectes sapidus, C. rathbunae and C. similis in a sub-tropical coastal lagoon of the Gulf of Mexico. J Crustacean Biol. 1994;14(2):371-82.

Safaie M, Kiabi B, Pazooki J, Shokri MR. Growth parameters and mortality rates of the blue swimming crab, Portunus segnis (Forskal, 1775) in coastal waters of Persian Gulf and Gulf of Oman, Iran. Indian J Fisheries. 2013a;60(1):9-13.

Safaie M, Pazooki J, Kiabi B, Shokri MR. Reproductive biology of blue swimming crab, Portunus segnis (Forskal, 1775) in coastal waters of Persian Gulf and Oman Sea, Iran. Iran J Fisheries Sci. 2013b;12(2):430-44.

Safaie M, Shokri MR, Kiabi B, Pazooki J. Biomass, CPUE and size frequency distribution of blue swimming crab Portunus segnis (Forskal, 1775) in coastal waters of the northern Persian Gulf, Iran. J Mar Biol Assoc U K. 2015:95(4):1-9.

Sanchez-Paz A, Garcia-Carreno FL, Muhlia-Almazan A, Peregrino- Uriarte AB, Hernandez-Lopez JY, Yepiz-Plascencia G. Usage of energy reserves in crustaceans during starvation: status and future directions. Insect Biochem Mol Biol. 2006;36:241-9.

Stehlik LL. Diets of the brachyuran crabs Cancer irroratus, C. borealis and Ovalipes ocellatus in the New York Bight. J Crustacean Biol. 1993;13(4):723-35.

Sukumaran KK. Fishery, biology and population dynamics of the marine crabs, Portunus (Portunus) sanguinolentus (Herbst) and Portunus (Portunus) pelagicus (Linnaeus) along the Karnataka coast. PhD Thesis. Dharwad, Karnataka, India: Karnataka University; 1995

Sukumaran KK, Neelakantan B. Food and feeding of Portunus (Portunus) sanguinolentus (Herbst) and Portunus (Portunus) pelagicus (Linnaeus) (Brachyura: Portunidae) along the Karnataka coast. Indian J Mar Sci. 1997;26(1):35-8.

Sumpton WD, Smith GS. Effect of temperature on the emergence activity and feeding of male and female sand crabs (Portunus pelagicus). Aust J Mar Freshwater Res. 1990:41(4):545-50.

Vinagre AS, Nunes do Amaral AP, Ribarcki FP, Fraga da Silveira E, Perico E. Seasonal variation of energy metabolism in ghost crab O. quadrata at Siriu Beach (Brazil). Comp Biochem Physiol. 2007;146:514-9.

Wieczorek SK, Hooper RG. Relationship between diet and food availablity in the snow crab Chionoecetes opilio (O. Fabricus) in Bonne Bay, Newfoundland. J Crustacean Biol. 1995;15(2):236-47.

Williams MJ. Methods for analysis of natural diet in portunid crabs (Crustacea: Decapoda: Portunidae). J Exp Mar Biol Ecol. 1981;52:103-13.

Williams MJ. Natural food and feeding in the commercial sand crab Portunus pelagicus Linnaeus, 1766 (Crustacea: Decapoda: Portunidae) in the Moreton Bay, Queensland. J Exp Mar Biol Ecol. 1982:59:165-76.

\section{Submit your next manuscript to BioMed Central and we will help you at every step:}

- We accept pre-submission inquiries

- Our selector tool helps you to find the most relevant journal

- We provide round the clock customer support

- Convenient online submission

- Thorough peer review

- Inclusion in PubMed and all major indexing services

- Maximum visibility for your research

Submit your manuscript at www.biomedcentral.com/submit 